\title{
The impact of municipal solid waste disposal in Ado- Ekiti metropolis, Ekiti-State, Nigeria
}

\author{
S. O. Adefemi and E. E. Awokunmi \\ ${ }^{1}$ Department of Chemistry, University of Ado-Ekiti, P. M. B. 5363, Nigeria. \\ Accepted 14 July, 2009
}

\begin{abstract}
Soil samples from four public waste dump sites (three samples from each location at $10 \mathrm{~m}$ interval) and plant sample (root and leave) from Igbaletere dump site were analyzed for heavy metals such as $\mathrm{Cu}, \mathrm{Mn}$, $\mathrm{Fe}, \mathrm{Cr}, \mathrm{Pb}, \mathrm{Co}, \mathrm{Zn}$ and $\mathrm{Ni}$. On the average, high concentrations of $\mathrm{Cu}, \mathrm{Mn}, \mathrm{Fe}, \mathrm{Pb}$, and $\mathrm{Zn}$ were found in the soil samples collected at the centre of the dump sites that is, $231.55,292.03,158.55$ and $205.40 \mathrm{mg} / \mathrm{g}$ respectively. The lower concentration was obtained in the soil samples taken at distance $20 \mathrm{~m}$ away from the centre of dumpsites, $\mathrm{Mn} 64.20, \mathrm{Fe} 110.65, \mathrm{~Pb} 213.00$ and $\mathrm{Zn} 66.86 \mathrm{mg} / \mathrm{g}$ respectively. The upland location of these refuse dump sites to the adjoining wells and the potential use of the dump soil for compost could cause environmental hazard. In the plant sample, concentration of $\mathrm{Fe}(341.94 \mathrm{mg} / \mathrm{g})$ was found to be the highest in the root, while concentrations of $\mathrm{Mn}(109.69 \mathrm{mg} / \mathrm{g})$ the highest in the leaf. The concentration of heavy metals in the roots of plant from Igbaletere dump site was correlated with the concentration of heavy metals in the soil samples from the dump site. The value of 0.9985 correlations, 0.051 alienation and $94.49 \%$ incidence of forecasting established a relationship between the plant and the soil of Igbaletere dump site.
\end{abstract}

Key words: Refuse, dumpsite, heavy metals, plants.

\section{INTRODUCTION}

Solid wastes other than hazardous and radioactive material are often referred to as Municipal Solid Waste (MSW). Municipal Solid Waste is useless unwanted material discharged as a result of human activity. Most commonly, they are solids, semi solids or liquids in containers thrown out of houses, commercial or industrial premises (Nyangababo and Hamya, 1980). Municipal Solid Waste varies in composition, which may be influenced by many factors, such as culture affluence, location etc. Municipal Solid Waste management depends on the characteristic of the solid waste including the gross composition, moisture contents, average particle size, chemical composition and density, in which knowledge of these, usually helps in disposal plans (Sally, 2000).

In Nigeria today, urban centers are experiencing an increased rate of environmental deterioration, with refuse dumped along drainage channels. Most cities in Nigeria are faced with waste Management problems, which AdoEkiti is not an exemption.

The environmental impact assessments of heavy metals

\footnotetext{
*Corresponding author. E-mail: adefemisamuel@yahoo.com.
}

present in our environment have been well documented (Ipinmoroti et al., 1970). However, the need for continued and effective monitoring of some heavy metals to source and distribution in the environment is highly necessary.

Most heavy metals occur at varying extents within all components of the environment. Thus heavy metals pollution of the environment does not mean unusual occurrence of a metal within a component; rather it represents the occurrence of that metal relative to the natural occurrence. They are present in trace concentrations in soil and vegetation and much more prominent in solid wastes containing non-biological and used products (Thomton, 1982).

There have been increased concerned about lead in the environment, which comes mainly from the use of lead as anti-knock additive to petrol. Lead is toxic even at low concentration and has no known function in biochemical process (Haggins and Burns, 1975).

The incorporation of Zinc and Cadmium in the manufacture of tyre is a good source of such metals from tyre abrasion (David and Williams, 1975). Also, a proven source of Nickel and Chromium is the wearing of mechanical parts of vehicles (Evans et al., 1980). It is equally added that increased use of metal based fertilizers in the 
agricultural revolution of government could result in a continued rise in the concentration of metal pollutants (Adefemi et al., 2008).

Stephens et al. (1972) reported the presence of As, $\mathrm{Cr}$ and $\mathrm{Cu}$ is associated with sludge incineration. They also stated that heavy metals can be introduced through high tension electricity supply lines, municipal solid wastes and building materials (Smith, 1976).

A metal can be toxic, if it impedes the growth or metabolism of cells that is present above a given concentration. Almost all metals are toxic at high concentrations. Copper, for example is a micro element, it is a necessary constituent of all organisms, but if the copper concentration increased above normal level, it becomes highly toxic. An increase in concentration of copper in the ocean by one part per billion has resulted in the death of several species of phytoplankton and the eggs of some fish of Open Ocean (Sommers et al., 1976).

However, this research work examines the effects of Municipal Solid Waste disposal in Ado metropolis, with a view of creating environmental awareness for both the Government and the public about the states of various dump sites in the metropolis.

\section{MATERIALS AND METHODS}

\section{Sampling}

Twelve Soil samples (from topsoil $1-15 \mathrm{~cm}$ deep) were taken from four designated dumpsites in Ado-Ekiti and plant (Amaranthus cruentus) sample (root and leaves) from Igbaletere dump site. Three soil samples were taken from the centre of the dump sites. All samples were collected same day and kept in polythene bags which have been washed with detergents solution rinsed with distilled water to avoid metal contamination of the sample. The plant sample was sun dried, grinded with grinding machine and stored in sample bottles.

\section{Soil sample}

The soil particulates samples were air dried and then passed through a $1 \mathrm{~mm}$ stainless steel sieve. One gram of each soil sample was put into $150 \mathrm{ml}$ conical flask, a mixture of $\mathrm{HNO}_{3}$ : $\mathrm{HCLO}_{4}$ : $\mathrm{HF}$ the ratio 3:1:3 was added (Nwajei and Gagophien, 2000). The mixture was placed on a hot plate for three hours at $80^{\circ} \mathrm{C}$. The digest was filtered into $100 \mathrm{ml}$ standard flask and made to mark with deionized water.

$2 \mathrm{~g}$ of plant samples (root and leaf) from Igbalatere dump site were dry-ashed in an oven. The ash content was completely dissolved in $15 \mathrm{ml}$ of $20 \% \mathrm{HNO}_{3}$ (Amusan et al., 2005). The digest was filtered into $100 \mathrm{ml}$ standard flask and made up to mark with deionized water. Heavy metals were analyzed for both in the sediment and plant samples using atomic absorption spectroscopy (Perkin Elmer Model 306).

\section{Statistical analysis}

All data generated were analyzed statistically by calculating mean, coefficient of correlation, alienation and incidence of forecasting efficiency.

\section{RESULTS AND DISCUSSION}

Table 1 shows the mean concentration of heavy metals in the soil samples from all the dump sites. On the average, the concentrations $(\mathrm{mg} / \mathrm{g})$ of Manganese (231.5a, $112.85 \mathrm{~b}$ and $69.20 \mathrm{c})$, Iron (297.03a, 149.49b and 10.65c), Lead (158.55a, 32.56b and 2.13c) and Zinc (205.40a, 70.65b and 66.86c) are exceptionally high. Similar observations have been reported on Bode-Osi dump site and Obafemi Awolowo University central refuse dump respectively (Alloway and Davies, 1971; Amusan et al., 2005).

It is also revealed from Table 1 that there is an obvious gradual reduction in the concentration of heavy metals as we move few meters away from the center of the dump site of a particular location. For example, from location $1 \mathrm{a}-\mathrm{c}$, iron concentration are $1 \mathrm{a} 248.27,1 \mathrm{~b} 83.86$ and 1c $62.60 \mathrm{mg} / \mathrm{g}$. This is the general trend for all the dump sites under examination.

In all of the samples, Iron has the highest mean concentration (297.03a, 149.49b and $110.65 \mathrm{c} \mathrm{mg} / \mathrm{g}$ ). This is because the dump sites are enriched with iron through metals deposition. Besides, iron has earlier been reported to be the most abundant mineral in Nigerian soil (Amusan et al., 2005).

The investigation of the concentration of heavy metals in the soil of dump sites was restricted to the top $15 \mathrm{~cm}$. The surfaces of the soil are better indicators of metallic burdens (Davies, 1973).

The concentration $(\mathrm{mg} / \mathrm{g})$ of heavy metals in the roots and leaves of plant ( $A$. cruentus) from Igbalatere dump is shown in Table 2. The concentration of the heavy metals examined ranged from ND-341.94 mg/g. The highest concentration $(341.94 \mathrm{Ng} / \mathrm{g})$ of iron was found in the root of the plant. Also, in all the heavy metals in the leaves of the plant, manganese has the highest concentration $(109.69 \mathrm{mg} / \mathrm{g})$. Cobalt was not detected in any parts of these plants.

It is believed that hilly terrain in the site will allow effective washing away of most of the heavy metals. This is particularly harmful to the lowland community, since the metals would be eventually washed by erosion into the adjoining wells (Slack et al., 2005) In addition to this, farmers rely on the biodegraded dump for compositing not minding the effect of such an unwholesome cost cutting techniques.

The high correlation $(0.9985)$ of the metals examined in the soils and plants from Igbalatere dump site indicates similarities in the origin of the metals. Also 0.051 alienation is showing very close relationship between the concentration of heavy metal in soil and weed plants. Lastly, $94.90 \%$ incidence of forecasting efficiency indicated the reliability of the results plant sample is the ability of plants to take up metals either as mobile ions present in the soil solution through the roots or through foliar adsorption (Chapel, 1986). The uptake of the metals by crops results in the bioaccumulation of these elements in plant tissues. Indeed, it has been reported that plant grown on soils 
Table 1. Concentration ( $\mathrm{mg} / \mathrm{g}$ ) of heavy Metals in Soil from Dump sites of selected locations in Ado-Ekiti.

\begin{tabular}{|c|c|c|c|c|c|c|c|c|c|c|}
\hline \multirow{2}{*}{\multicolumn{3}{|c|}{ Location/Mean Distance }} & \multicolumn{8}{|c|}{ Heavy metals } \\
\hline & & & \multirow{2}{*}{$\frac{\mathrm{Cu}}{12.38}$} & \multirow{2}{*}{$\frac{\mathrm{Mn}}{246.28}$} & \multirow{2}{*}{$\frac{\mathrm{Fe}}{248.28}$} & \multirow{2}{*}{$\begin{array}{c}\mathrm{Cr} \\
10.17\end{array}$} & \multirow{2}{*}{$\frac{\mathbf{P b}}{313.35}$} & \multirow{2}{*}{$\begin{array}{c}\text { Co } \\
10.62\end{array}$} & \multirow{2}{*}{$\begin{array}{c}\mathrm{Zn} \\
98.22\end{array}$} & \multirow{2}{*}{$\frac{\mathbf{N i}}{\mathrm{ND}}$} \\
\hline & $a$ & Center of dump & & & & & & & & \\
\hline \multirow[t]{3}{*}{1} & $b$ & $10 \mathrm{~m} \mathrm{a}$ & 2.18 & 117.16 & 83.67 & 2.77 & 72.31 & 5.82 & 32.05 & ND \\
\hline & c & 20 m away & 1.45 & 62.60 & 70.54 & 1.85 & & ND & 18.61 & ND \\
\hline & a & Center of dump & 24.07 & 278.54 & 358.92 & 13.87 & & 11.64 & 201.61 & 2.36 \\
\hline \multirow[t]{3}{*}{2} & $b$ & 10 m away & 8.01 & 211.92 & 232.37 & 10.17 & 14.28 & 1.64 & 50.66 & 2.36 \\
\hline & c & $20 \mathrm{~m}$ away & 1.46 & 106.82 & 179.11 & 2.77 & 1. & ND & 129.24 & ND \\
\hline & a & Center of dump & 3.64 & 296.35 & 311.89 & 22.20 & 149.53 & 3.49 & 72.47 & ND \\
\hline \multirow[t]{3}{*}{3} & $\mathrm{~b}$ & $10 \mathrm{~m}$ away & 3.64 & 123.48 & 204.01 & 6.47 & 117.97 & 2.33 & 63.07 & 3.55 \\
\hline & c & 20 m away & 3.64 & 92.45 & 34.63 & 7.40 & 2.25 & 1.16 & 40.32 & 1.18 \\
\hline & $\mathrm{a}$ & Center of dump & 67.78 & 53.41 & 208.16 & 5.55 & 51.85 & 4.66 & 95.12 & 1.18 \\
\hline \multirow[t]{3}{*}{4} & $\mathrm{~b}$ & 10 m away & 57.5 & 45.37 & 112.72 & 4.62 & 18.79 & 2.33 & 58.73 & 1.18 \\
\hline & c & 20 m away & 5.09 & 4.02 & 127.94 & 2.77 & 0.75 & 1.16 & 57.90 & ND \\
\hline & $\mathrm{a}$ & Center of dump & 42.21 & 231.55 & 297.03 & 10.82 & 158.05 & 8.18 & 205.40 & 4.92 \\
\hline \multirow[t]{2}{*}{ Mean } & b & 10 m away & 15.56 & 112.85 & 149.49 & 6.16 & 32.56 & 4.93 & 20.65 & 1.18 \\
\hline & $\mathrm{C}$ & 20 m away & 4.37 & 69.20 & 110.65 & 3.65 & 2.15 & 1.55 & 66.86 & 0.59 \\
\hline
\end{tabular}

1-Okutagbokutaleri dump.

2-Igbaletere dump.

3-Oke age dump.

4-Mary Immaculate dump.

ND- not detected.

Table 2. Showing the concentration $(\mathrm{mg} / \mathrm{g})$ of heavy metals in the roots and leaves of plant from Igbaletere dump site.

\begin{tabular}{ccccccccc}
\hline Location/Metal & $\mathbf{C u}$ & $\mathbf{M n}$ & $\mathbf{F e}$ & $\mathbf{C r}$ & $\mathbf{P b}$ & $\mathbf{C o}$ & $\mathbf{Z n}$ & $\mathbf{N i}$ \\
\hline $5 \mathrm{a}$ & 21.05 & 245.94 & 341.94 & 12.02 & 185.31 & $\mathrm{ND}$ & 185.07 & 1.18 \\
$5 \mathrm{~b}$ & 2.18 & 109.69 & 69.85 & 1.85 & 7.51 & $\mathrm{ND}$ & 22.75 & $\mathrm{ND}$ \\
\hline
\end{tabular}

possessing enhanced metals concentration due to pollution has increased heavy metals content (Grant and Dobbs, 1977). If the consumption of these plants is not carefully regulated, it may lead to accumulation in man with attendant health hazards.

In conclusion, many studies have shown that heavy metal is hazardous at high concentration, looking at the concentration of the heavy metals in the soil and plant samples (Tables 1 and 2), it is obvious that the soil and plant will constitute a serious threat to the health of people living around such areas. This can be controlled by adopting a good waste management approach to the waste disposal.

\section{REFERENCES}

Adefemi SO, Asaolu SS, Olaofe O (2008). Determination of heavy metals in Tilapia mossabicus fish, associated water and sediments from Ureje dam South-Western Niger. Res. J. Environ. Sci. 2(2): 151155.

Alloway BJ, Davies BE (1971). Heavy metal content of plants growing on soil contaminated by lead mining. J. Agric. Sci. Cambrdge 3(2): 321-323.
Amusan AA, Ige DV, Olawale R (2005). Characteristic of Soil and Crop uptake of metals in municipal waste dump sites in Nig. J. Human Ecol. kamla Rja 1(2):167-171

Chapel A (1986). Foliar fertilization in Matrius Nijhoff dordrecht, A. Alexander Stuggard Ed. 66086.

Davies BE (1973). A graphical estimation of normal lead content of some British Soils, Geoderma 2(3): 67-75.

Evans OH, Wiener JG, Horton JH (1980). Trace elements inputs from a coal burning power plant adjacent to Terrestrial and Aquatic environ. J. Air Pollut. Control Dervy Assoc. 1(2): 60-65.

Grant C, Dobbs AJ (1977). The growth and metal content of plants grown in soils contaminated by a copper/ chrome/arsenic wood Preservative. J. Environ. Pollut. 14: 213-226.

Haggins IJ, Burns RG (1975). The Chem. and Microbiol. of Pollution. Academic press, New York $5^{\text {th }}$ ed. p.1248.

Ipinmoroti KO, Asaolu SS, Adeeyinwo CE, Olaofe O (1970). Distribution of some heavy metals in the coastal water of Ondo state Niger. J. Technol. Sci. 1(1): 46 .

Nwajei PE, Gagophein PO (2000). Distribution of heavy metals in the sediments of Lagos Lagoon. Pak. J. Sci. Ind. Res. 43: 338-340.

Nyangababo JT, Hamya JW (1980). The Deposition of Lead, Cadmium, Zinc and Copper from Motor Traffic on Bradaria Enimi and Soil along a major Bombo road. Int. J. Environ. Stud. Legol 1 (32): 117.

Sally W (2000). Contrl of Municipal Solid Wastes. Oxford Univer. Press, Oxford $6^{\text {th }}$ eds. p.642.

Slack RJ, Gronov JR, Voulvoulis N. (2005) Household hazardous waste in municipal landfills: contaminant in leachate. Sci. Total Environ. 
337: 119-137.

Smith KM. (1976). Soil Chem, Willey and Son Inc., U. S. A. $6^{\text {th }}$ Ed. 6. Sommers LE, Nelson DW, Yost KJ (1976). Variable Nature of Chem. Composition of Sewage Gouges. J. Environ. Stud. Massachusetts 1(5): 303-306.
Thomton I (1982). Geochem aspects of the distribution and forms of heavymetals. Elsevier publishers 2(2): 3-11. 